\title{
Assessment of Field-Grown Cucurbit Crops and Weeds within Farms in South-West Nigeria for Viral Diseases
}

\author{
Emily I. AYO-JOHN ${ }^{1 *}$, Patience M. OLORUNMAIYE², Olusola O. ODEDARA ${ }^{3}$, \\ Olusayo B. DADA ${ }^{1}$, Kolade O. ABIOLA ${ }^{1}$, John O. OLADOKUN ${ }^{1}$ \\ ${ }^{1}$ Federal University of Agriculture, Department of Crop Protection, PMB 2240, Alabata, Abeokuta, Ogun State, Nigeria; \\ eiayojobn@hotmail.com (*correspondingauthor) \\ ${ }^{2}$ Federal University of Agriculture, Department of Plant Physiology and Crop Production, PMB 2240, Alabata, Abeokuta, Ogun State, Nigeria \\ ${ }^{3}$ Federal University of Agriculture, Department of Microbiology, PMB 2240, Alabata, Abeokuta, Ogun State, Nigeria
}

\begin{abstract}
Cucurbits are economic crops in Nigeria which serve as additional nutritional supplements and also good sources of income for farmers. Viral diseases are a worldwide problem of cucurbits and a major limiting factor for cucurbit production. A survey of farmer's fields where cucurbit crops were grown was carried out to assess the incidence and severity of virus symptoms and viruses associated with the crops and weeds in selected locations in Ogun and Osun, in southwest Nigeria, in June, 2012. In all, 38 leaf samples were collected in Ogun state and 52 in Osun state from cucurbit crops and weeds. Leaf samples were tested against Cucumber mosaic virus (CMV), Melon necrotic spot virus (MNSV), Papaya ringspot virus (PRSV), Watermelon mosaic virus (WMV), Zucchini yellow mosaic virus $(Z Y M V)$ and Cucumber green mottle mosaic virus (CGMMV) using Double Antibody Sandwich (DAS) enzyme-linked immunosorbent assay (ELISA). All the fields surveyed had virus symptom incidences of $100 \%$ except for melon fields in Osun state with incidences of between 10 and 30\%. In Ogun state, the occurrence of CMV was 5/31 (16.1\%) while MNSV was detected in Lagenaria siceraria and T. occidentalis and it occurred in 6.5\% of the leaf samples. In Osun state, CMV was detected in watermelon, melon and weeds found in all locations surveyed. The occurrence of CMV was 9/38 (23.7\%) in the cucurbit crops and in $78.6 \%$ $(11 / 14)$ of the weeds. PRSV and WMV also occurred in mixed infection with CMV in $7.1 \%$ respectively. CMV was the most widespread and prevalent virus infecting cucurbit crops and weeds.
\end{abstract}

Keywords: cucurbits, ELISA, pumpkin, survey, virus detection, watermelon

\section{Introduction}

Cucurbits, which include cucumber, watermelon, pumpkin, muskmelon, summer squash and gourds, are some of the most popular garden vegetables planted today. Cucurbits belong to the family Cucurbitaceae. The family has 130 genera and 825 species (Renner et al. 2007). The fruits of the family Cucurbitaceae could be eaten fresh or cooked or preserved in different ways. Their flesh contains small amount of starch, sugars, protein fats as well as vitamin $\mathrm{B}$ complex, some carotenes and vitamin $\mathrm{C}$. Their leaves and flowers can be cooked as vegetables (Paris, 1989). In subSaharan Africa, the indigenous species are prized for their oleaginous seeds consumed as thickeners of traditional soup called egusi soup in Nigeria or Benin and pistachio soup in Cote d'Ivoire. Cultivated cucurbits for seed consumption are also reported to be rich in nutrients.

Cucurbits are economic crops in Nigeria which are not only taken to overcome nutritional deficiency but are also good sources of income for farmers. Cucumber is grown for its fruits which is eaten fresh or as salad with other vegetables. Telfairia occidentalis is a tropical vine grown in West Africa as a leaf vegetable and for its edible seeds. The leaves are rich sources of iron $(\mathrm{Fe})$ and can therefore be used for treatment of anaemia (Alada, 2000). Akoroda in 1990 observed that $T$. occidentalis is a common homestead garden crop in southern Nigeria and is mostly cultivated by women.

Generally, the set of factors that limit the production of cucurbit crops are usually similar. Nevertheless, their susceptibility to the various pests and diseases varies considerably from crop to crop. Insect pest like the aphids (Aphis gossypii, which transmit viral pathogens), Squash bug (Anasa tristis, which suck the sap of squash and pumpkins leading to crisping and wilting), Squash vine borer (Melittia cucurbitae, which burrows into squash and pumpkin vines causing wilting) all pose a threat to the global production of cucurbits. Viral diseases are a worldwide problem of cucurbits and a major limiting factor for cucurbit 
322

production (Lira, 1991). Almost 35 different viruses have been isolated from Cucurbitaceae (Provvidenti, 1996). Potyviruses affect cucurbit cultivation and three most frequent and economically important potyviruses are Zucchini yellow mosaic virus (ZYMV), Water melon mosaic virus (WMV) and Papaya ringspot virus (PRSV) (Lecoq et al., 2001).

Despite the importance of cucurbits in Nigeria, very limited information is available at the local level on the incidence of viral diseases. Fluted pumpkin, watermelon and cucumber have become economic crops of great importance in southwest today; this study is carried out to provide useful information on the viral strains and diseases prevalent in selected areas. Such type of information is essential for the development of effective virus control strategies. Hence the objective of this study was to determine the incidence of virus symptoms and viruses infecting field grown cucurbit crops and weeds which may also serve as reservoir hosts in Ogun and Osun states in Southern Nigeria.

\section{Materials and methods}

\section{Virus survey}

Leaf samples were collected from fluted pumpkin, watermelon, melon and gourd crops in three Local Government Areas of Ogun state namely Ifo, Ewekoro and Odeda and also at Iwo, Ola-Oluwa and Aiyedire Local Government Areas in Osun state. Farmer's fields and home gardens of cucurbit crops were examined for virus-like symptoms such as mosaic, mottle, leaf reduction, leaf distortion, etc. The fields were inspected visually and ten leaf samples were collected in each field. Also 3 leaf samples were taken within $50 \times 50 \mathrm{~cm}$ quadrates on the field where weeds were present. The leaf samples were placed in labelled sample bags and preserved in a cooling box with ice while in transit. Thereafter, the samples were taken to the Laboratory for virus indexing using enzyme linked immunesorbent assay (ELISA).

\section{Determination of disease incidence}

Disease incidences were estimated for each farm based on plants found along a $10 \mathrm{~m}$ diagonal transect set at the middle of the farm by counting the number of plants showing virus-like symptoms expressed as a percentage of the total number of plants along the diagonal transect as shown in the equation below where:

$$
\begin{aligned}
& \text { Disease incidence }(\%)=\frac{\text { No of plants showing symptom }}{\text { Total number of plants }} \times 100 \\
& \text { (Allen } \text { et al., 1983) }
\end{aligned}
$$

\section{Determination of disease severity}

Virus symptom expressions were rated on plants along the diagonal transect using a modification of the scale developed by Hassan and Al-masri (1991) where: 1 - No symptom, 2 - Mild symptom (10\% of leaves), 3 - Moderate symptom (10-30\%), 4 - Severe symptom (30-50\%), 5 - Leaf distortion and death (over 75\%).

\section{Indexing for viruses using DAS-ELISA}

Six viruses Zucchini yellow mosaic virus (ZYMV), Water melon mosaic virus (WMV), Papaya ringspot virus (PRSV), Cucumber green mottle mosaic virus (CGMMV), Cucumber mosaic virus (CMV), and Melon necrotic spot virus (MNSV) were indexed for using DAS-ELISA as described by Clark and Adams (1977) with specific polyclonal antibodies. Leaf samples $(0.1 \mathrm{~g})$ were homogenized in extraction buffer $(8.0$ $\mathrm{g} \mathrm{NaCl}, 0.2 \mathrm{~g} \mathrm{KH}_{2} \mathrm{PO}_{4} 1.1 \mathrm{~g} \mathrm{Na}_{2} \mathrm{HPO}_{4}, 0.2 \mathrm{~g} \mathrm{KCl} / \mathrm{L}, \mathrm{pH}$ 7.4 ) containing $0.05 \% \mathrm{v} / \mathrm{v}$ Tween 20 , and $2 \% \mathrm{w} / \mathrm{v}$ polyvinylpyrrolidone. Each ELISA plate was coated with one of CGMMV, CMV, WMV, PRSV, MNSV $1 \mathrm{gG}$ respectively diluted 1 in 1000 according to manufacturer's specification in coating buffer $\left(1.59 \mathrm{~g} \mathrm{Na}_{2} \mathrm{CO} 3,2.93 \mathrm{~g}\right.$ $\mathrm{NaHCO}_{3} \mathrm{pH}$ 9.6) into each well of the plates and incubated at $37^{\circ} \mathrm{C}$ for 2 hours. The plates were washed three times at three minutes interval with washing buffer (PBS-T) from a wash bottle. Using a pipette, $100 \mu$ of the sap were pipetted into each well and incubated overnight at $4^{\circ} \mathrm{C}$. The plates were decanted and washed as earlier described before adding $100 \mu \mathrm{l}$ antibody enzyme conjugate with alkaline phosphatase diluted 1 in 1000 in conjugate buffer (PBS-T, $2 \%$ PVP and $0.2 \%$ albumen was pipetted into the wells of the plates and incubated at $37^{\circ} \mathrm{C}$ for 2 hours. The plates were washed as described before addition of $200 \mu \mathrm{l}$ of $1 \mathrm{mg} / \mathrm{ml} \mathrm{P-nitrophenyl} \mathrm{phosphate} \mathrm{(PNP)} \mathrm{in} \mathrm{substrate}$ buffer. The plates were incubated at room temperature for 60 minutes to obtain clear reactions and the absorbance of the well contents read at $405 \mathrm{~nm}$. The samples with positive reaction to CGMMV, CMV, WMV, PRSV, MNSV and ZYMV were observed when the absorbance value at $405 \mathrm{~nm}$ doubled that of the healthy control samples.

\section{Results}

\section{Virus survey}

In Ogun state 38 cucurbit samples comprising nine watermelon (Citrulus lanatus), 10 large African gourd (Lagenaria siceraria), 19 pumpkin (Telfairia occidentalis) and the weed samples, Synedrella nodiflora and Commelina benghalensis were collected within one farm. All the fields surveyed had virus symptoms resulting in 100\% field incidences. The symptom severity score was 4 (severe) for the cucurbit crops found in Ewekoro and Coker farm in Ifo (Tab. 1). The major virus symptoms encountered were mosaic and leaf distortion, yellowing, necrosis for watermelon crops, mosaic on African gourd and mosaic, mottle and leaf distortion for T. occidentalis.

The field incidence observed for the four locations within the three local government areas were $100.0 \%$, for Ewekoro and Ifo while, Akinside was observed to be apparently healthy and Odeda $10.0 \%$ (Tab. 1).

In Ifo and Ewekoro Local Government Areas, virus symptoms were severe with severity score of 4 . In contrast, severity score of 1 was recorded for Akinside meaning no symptom, while Odeda had a severity score of 2 meaning mild symptoms (Tab. 1).

In addition, 52 leaf samples were collected in Osun state (19 watermelon samples, 19 melon samples and 14 weed samples. The watermelon farms in Osun state had 100\% incidence of virus symptoms while it was between 10 and $30 \%$ in melon fields. Similarly the degree of symptom expression was moderate and severe $(3$ and 4$)$ for the watermelon fields while it was mild (2) for melon fields (Tab. 1). 
Tab. 1. Incidence and symptom severity of virus symptoms on cucurbit crops grown within the three locations in Ogun and Osun states in June 2012

\begin{tabular}{|c|c|c|c|c|c|c|c|}
\hline $\begin{array}{l}\text { Ogun } \\
\text { LGA }\end{array}$ & Farm site & Crop & $\begin{array}{c}\% \\
\text { incidence }\end{array}$ & $\begin{array}{c}\text { Mean } \\
\text { symptom } \\
\text { severity }\end{array}$ & Cropping system & $\mathrm{N}$ & E \\
\hline Ewekoro & Olujobi & $\begin{array}{l}\text { Watermelon \& } \\
\text { African Gourd }\end{array}$ & 100.0 & 4 & Mixed & $06.95337^{0}$ & 003.19107 \\
\hline Odeda & Camp & Pumpkin & 10.0 & 2 & Sole & $06.46456^{0}$ & 003.08767 \\
\hline \multirow{2}{*}{ Ifo } & Akinside & Pumpkin & 0.0 & 1 & Mixed & $06.80957^{0}$ & 003.16589 \\
\hline & Coker & Watermelon & 100.0 & 4 & Sole & $06.77230^{\circ}$ & 003.14812 \\
\hline \multicolumn{8}{|l|}{$\begin{array}{l}\text { Osun } \\
\text { LGA }\end{array}$} \\
\hline Iwo & Aboomosun & Watermelon & 100 & 4 & Mixed & 07.68515, & 004.12900 \\
\hline Aiyedire & Ahoro & Watermelon & 100 & 2 & Mixed & 07.64514, & 004.22796 \\
\hline \multirow{2}{*}{ Olaoluwa } & Bode-Osi & Egusi-melon & 30 & 2 & Sole & 07.75002, & 004.22569 \\
\hline & Asa-Oke-odo & Egusi-melon & 10 & 3 & sole & 07.78789, & 004.22759 \\
\hline
\end{tabular}

Tab. 2. Distribution of virus-like symptoms on cucurbit crops grown in Ogun state in June 2012

\begin{tabular}{ccccc}
\hline Crop & $\begin{array}{c}\text { Mosaic } \\
+ \text { distortion }\end{array}$ & $\begin{array}{c}\text { Mottle+ } \\
\text { distortion }\end{array}$ & $\begin{array}{c}\text { Necrosis, } \\
\text { Yellowing, } \\
\text { distortion }\end{array}$ & $\begin{array}{c}\text { Apparently } \\
\text { Healthy }\end{array}$ \\
\hline Watermelon & $3 / 9(33.3)$ & $\begin{array}{c}3 / 9 \\
(33.3)\end{array}$ & $2 / 9(22.2)$ & $1 / 9(11.1)$ \\
Lagenaria & $8 / 10$ & $1 / 10$ & $1 / 10$ & $0 / 10(0)$ \\
siceraria & $(80.00)$ & $(10.00)$ & $(10.0)$ & \\
Pumpkin & $6 / 19(31.6)$ & $\begin{array}{c}11 / 19 \\
(57.9)\end{array}$ & $\begin{array}{c}2 / 19 \\
(10.5)\end{array}$ & $0 / 19(0)$ \\
\hline
\end{tabular}

Tab. 3. Distribution of virus symptoms on cucurbit crops grown in Osun state in June 2012

\begin{tabular}{|c|c|c|c|c|}
\hline Crop & $\begin{array}{c}\text { Mosaic + } \\
\text { Distortion }\end{array}$ & $\begin{array}{l}\text { Yellowing } \\
\text { + necrosis }\end{array}$ & Mottle & $\begin{array}{c}\text { Apparently } \\
\text { Healthy }\end{array}$ \\
\hline Egusi-melon & $\begin{array}{l}11 / 19 \\
(57.9)\end{array}$ & $\begin{array}{l}4 / 19 \\
(44.4)\end{array}$ & $\begin{array}{c}3 / 19 \\
(33.3)\end{array}$ & $1 / 19(10.3)$ \\
\hline Watermelon & $\begin{array}{l}10 / 19 \\
(52.6)\end{array}$ & $\begin{array}{l}9 / 19 \\
(47.4)\end{array}$ & 0.0 & 0.0 \\
\hline
\end{tabular}

${ }^{\bar{N}} \mathrm{~N} . \mathrm{S}=$ Necrotic spots, R. L = Reduced leaf, A. P = Apparently healthy, V. B $=$ Vein banding, V. C = Vein clearing

\section{Distribution of virus symptoms on cucurbit crops}

The major virus symptoms on watermelon were mosaic and mottle plus leaf distortion with $33.3 \%$ occurrence respectively. The large African gourd was observed with mosaic and leaf distortion in $80.0 \%$ of the leaf samples. For Pumpkin the most prevalent virus symptom was mottling and leaf distortion which was observed in $57.9 \%$ of the leaf samples (Tab. 2). In Osun state the cucurbit crops were melon and watermelon. On the melon, yellowing and necrosis were observed followed by mottle symptoms in $44.4 \%$ and $33.3 \%$ of the samples respectively (Tab. 3), while for watermelon it was mosaic (52.6\%) and yellowing and necrosis (47.4\%) as shown in Tab. 3.

\section{Virus symptoms observed in weed samples}

Weeds samples were collected from locations that had weeds during the survey. In Ogun state, weed samples were collected from one location in Akinside in Ifo Local Government Area. The weed samples were Synedrella nodiflora and Commelina benghalensis with symptoms of mosaic. Fourteen other weed species were collected in Osun state and the weeds showed various symptoms of reduced leaf, yellowing and necrosis, vein banding, crinkling, mosaic and vein clearing.

Detection of viruses in cucurbit and weed leaf samples

In Ogun state CMV and MNSV were detected in $T$. occidentalis, Lagenaria siceraria and $S$. nodiflora leaf samples. Most leaf samples reacted negatively with polyclonal antibodies to PRSV, CGMMV, WMV and ZYMV (Tab. 4). The occurrence of CMV was 5/31 (16.1\%) while MNSV was detected in Lagenaria siceraria and $T$. occidentalis and the occurrence was 6.5\% (Tab. 4). In Osun state, CMV was detected in watermelon, melon in $23.7 \%$ (9/38) of the cucurbit crops (Tab. 5). WMV and PRSV were detected only on the weed samples. CGMMV, MNSV and ZYMV were not detected in the leaf samples collected. The occurrence of CMV was 11/14 (78.6\%) while WMV and PRSV each occurred in $1 / 14(7.1 \%)$ of the weed samples respectively (Tab. 6).

\section{Discussion}

This report presents one of the first surveys on virus diseases of cucurbit crops in southwest Nigeria where the crops are rapidly gaining preferences both by the growers and consumers alike. Many farmers now plant watermelon and cucumber as part of their cropping system, however during the survey; it was observed that losses were incurred by the farmers due to pest and disease attack. Virus diseases were observed in all farms surveyed and the disease incidences in the locations surveyed ranged from $10 \%$ (low) to $100 \%$ (high). This could be attributed to the fact that none of the farmers had adequate knowledge of viral 
324

diseases or of viruses, mode of transmission, symptoms, and magnitude of symptom expression as well as appropriate method of control. The intensification of cucurbit cultivation in these areas together with lack of control measures has probably led to high disease incidences that may result in low yield and fruits that have poor market value. The high cost, and or non-availability, of virus-free seeds has enhanced introduction of virus diseases.

Furthermore, the occurrence of viruses also indicated the susceptibility of the cultivars to virus infection.

Serological analysis of the leaf samples revealed that CMV was the most prevalent virus both in the cucurbit crops and weeds and in the two states surveyed in southwest Nigeria. Cucumber mosaic virus, which has being noted to

Tab. 4. Detection of viruses on cucurbit crops in three local government areas surveyed in Ogun state in June 2012

\begin{tabular}{cccccccc}
\hline Crops & $\begin{array}{c}\text { No of samples } \\
\text { tested }\end{array}$ & CMV (\%) & MNSV (\%) & PRSV (\%) & $\begin{array}{c}\text { CGMMV } \\
(\%)\end{array}$ & WMV (\%) & ZYMV (\%) \\
\hline Watermelon & 2 & $0 / 2(0)$ & $0 / 2(0)$ & $0 / 2(0)$ & $0 / 2(0)$ & $0 / 2(0)$ & $0 / 2(0)$ \\
Pumpkin & 19 & $3 / 19(15.79)$ & $1 / 19(5.26)$ & $0 / 19(0)$ & $0 / 19(0)$ & $0 / 19(0)$ & $0 / 19(0)$ \\
$\begin{array}{c}\text { Lagenaria } \\
\text { siceraria }\end{array}$ & 10 & $2 / 10(20.00)$ & $1 / 10(10.00)$ & $0 / 10(0)$ & $0 / 10(0)$ & $0 / 10(0)$ & $0 / 10(0)$ \\
\hline
\end{tabular}

Tab. 5. Detection of viruses on cucurbit crops in three local government areas surveyed in Osun state in June 2012

\begin{tabular}{cccccccc}
\hline Location/LGA & $\begin{array}{c}\text { No. of } \\
\text { samples }\end{array}$ & CMV $(\%)$ & $\begin{array}{c}\text { WMV } \\
(\%)\end{array}$ & $\begin{array}{c}\text { PRSV } \\
(\%)\end{array}$ & CGMMV & ZYMV & MNSV \\
\hline Watermelon & 11 & $2 / 11(18.2)$ & 0.0 & 0.0 & 0.0 & 0.0 & 0.0 \\
Watermelon & 8 & $3 / 8(37.5)$ & 0.0 & 0.0 & 0.0 & 0.0 & 0.0 \\
Egusi-melon & 19 & $4 / 19(21.1 \%)$ & 0.0 & 0.0 & 0.0 & 0.0 & 0.0 \\
\hline
\end{tabular}

Tab. 6. Detection of viruses in weed leaf samples collected from fields grown with cucurbit crops in Ogun and Osun States in June 2012

\begin{tabular}{|c|c|c|c|c|c|c|c|}
\hline Weeds & Plant Family & $\begin{array}{l}{ }^{*} \text { Growth } \\
\text { form }\end{array}$ & Symptom & Site (LGA) & $\mathrm{CMV}$ & WMV & PRSV \\
\hline \multicolumn{8}{|l|}{ Ogun State } \\
\hline Synedrella nodiflora Gaertn & Asteraceae & $\mathrm{ABL}$ & none & Ifo & + & - & - \\
\hline Commelina benghalensis $\mathrm{L}$. & Commelinaceae & PBL & none & & - & - & - \\
\hline \multicolumn{8}{|l|}{ Osun State } \\
\hline Spigelia anthelmia (Linn) & Asteraceae & $\mathrm{ABL}$ & $\begin{array}{c}\text { Mosaic } \\
+ \text { leaf dist }+ \text { Y }\end{array}$ & Ayedire & + & + & - \\
\hline $\begin{array}{c}\text { Acalypha fimbriata Schum. } \\
\text { \& Thonn }\end{array}$ & Euphorbiacea & $\mathrm{ABL}$ & mottling & & + & - & - \\
\hline Chromolaena odorata (L.) & Asteraceae & $\mathrm{ABL}$ & mottle & & + & - & - \\
\hline Indigofera birsuta (Linn) & Fabaceae & & Mild mottle & & - & - & - \\
\hline Acmilla brychyglossa & Asteraceae & $\mathrm{ABL}$ & mosaic & & + & - & - \\
\hline $\begin{array}{l}\text { Acanthospermum } \\
\text { hispidium Dc. }\end{array}$ & Asteraceae & $\mathrm{ABL}$ & $\begin{array}{c}\text { Vein } \\
\text { banding+chls }\end{array}$ & & + & - & - \\
\hline $\begin{array}{c}\text { Calopogonium mucuroides } \\
\text { Desv. }\end{array}$ & Fabaceae & PBL & none & Iwo & + & - & - \\
\hline $\begin{array}{c}\text { Calopogonium mucuroides } \\
\text { Desv. }\end{array}$ & Fabaceae & PBL & none & & + & & \\
\hline Spigelia anthelmia (Linn) & Asteraceae & $\mathrm{ABL}$ & Necrotic spots & & + & - & - \\
\hline Euphorbia hirta L. & Euphorbiaceae & $\mathrm{ABL}$ & mosaic & Olaoluwa & + & - & - \\
\hline Sida acuta Burm. f. & Malvaceae & PBL & Vein clearing & & - & - & - \\
\hline Senna sp. & Leguminoseae & $\mathrm{ABL}$ & Mosaic & & + & - & - \\
\hline E. hirtal. & Euphorbiaceae & $\mathrm{ABL}$ & mosaic & & + & - & + \\
\hline S. nodiflora Gaertn & Asteraceae & $\mathrm{ABL}$ & mosaic & & - & - & - \\
\hline
\end{tabular}


have the widest host range among plants was found to be the most prevalent viral pathogen in the surveyed cucurbit fields. A relative study carried out by Yuki $e t$ al. (2000) in Brazil also indicated 35\% incidence of CMV. CMV was present in about $78.6 \%$ of the weeds collected and tested. This explains the reason for the high disease incidence observed in virtually all the fields surveyed in spite of the farmers' claim to spray agro-chemicals. The annual and perennial broad leaf weeds present on the field may serve as sources of CMV. The virus is known to be seed-borne in many weed species; the perennial weeds may also be a continuous source of the virus if not eliminated from the cucurbit fields.

Also, the non-persistent mode of transmission of CMV by aphids makes the transmission and spread of the disease faster.

The incidence of virus on the different species of cucurbit crops surveyed showed that CMV was the most widely distributed and prevalent virus in Ogun and Osun states of southwest Nigeria. CMV has a very broad, host range, infecting more than 1200 plant species in over 100 families, including fruit crops, vegetables and ornamentals, both monocots and eudicots. CMV particles are transmitted in a stylet-borne, nonpersistent manner by more than 80 species of aphid in 33 genera, and many symptomless, overwintering weed hosts have been described. Seed transmission of CMV also occurs in many weeds, although with frequencies ranging from $<1 \%$ to $50 \%$ (Palukaitis and García-Arenal, 2003; Palukaitis et al., 1992). Tomlinson (1987) listed CMV as the virus of greatest economic importance in celery, cowpea, cucurbits, lettuce, pepper and tomato. The other virus detected in mixed infection with CMV was MNSV. The virus which is seed and soil-borne was detected in pumpkin and large African gourd leaf samples in Ogun state. The MNSV transmission can occur with the use of contaminated tools. The poor knowledge of farmers on virus symptoms and diseases they cause maybe the reason for little or no sanitary or control measures undertaken. MNSV causes severe symptoms and yield loss in melon (Sug-ju et al., 2007). The virus can also be transmitted through seed. A common practice among farmers' in the southwest of Nigeria is the use of seeds from previous seasons harvest for new planting. Where such seed were obtained from infected plants, could lead to infected seedlings that would serve as sources of primary inoculum in the field. The two other viruses were WMV and PRSV. WMV was detected in weeds collected within the cucurbit fields, the virus is aphid transmitted and its hostrange includes other non-cucurbit crop where the virus can survive between growing seasons. Eradication of weeds and alternate host can help reduce the incidence of the virus. PRSV is also aphid transmitted and cause serious diseases on cucurbit crops.

However, ZYMV, PRSV, CGMMV and WMV were not detected from the symptomatic cucurbit leaf samples collected. This may be due to infection by other viruses or as yet unidentified virus present in the states.

Our results provide essential basic information for the future introduction of virus control strategies in southwest Nigeria. Various management strategies could be employed to reduce virus infections on cucurbit crops. The most important strategy for control of virus diseases would include proper land cultivation to eliminate volunteer plants that harbour the virus, effective weed control and or development of resistant varieties. Although CMV is difficult to control due to numerous alternate hosts for the virus and its transmission by aphids in a non-persistent manner, an aggressive control of the aphid vectors should be adopted. For the seed and soil-borne MNSV soil disinfection and virus -free seeds may be used where available.

\section{Acknowledgement}

The authors are grateful to Dr. Stephan Winter for the antibodies used.

\section{References}

Alada ARA (2000). The Haematological Effect of Telfairia occidentalis Diet Preparation. AfrJ Biomedical Res 3:185-186.

Allen RN, Plumb RT, Thresh JM (1983). Spread of Banana Bunchy Top and other Plant Virus Diseases in Time and Space p. 51-59. In: Plumb RT, Thresh JM (Eds.). Plant Virus Epidemiology, Blackwell Scientific Publications, UK.

Akoroda MO (1990). Ethnobotany of T. occidentalis among Igbos of Nigeria. Economic Botany 44(1):29-39.

Clark MF, Adams AN (1977). Characteristics of the Microplate Method of Enzyme-Linked Immunosorbent Assay for the Detection of Plant Viruses. J General Virology 34: 4483.

Hassan AA, Quronfilah NE, Obaji UA, Al-Rays MA, Wafi MS (1991). Screening of domestic and wild C. Germplasm for resistance to yellow- stunting disorder in the United Arab Emirate. Cucurbit Genetic Cooperative Report 14: 98-101.

Lecoq H, Dafalla G, Desbiez C, Wipf-Scheibel C, Delecolle B, Lanina T, Ullah Z, Grumet R (2001). Biological and molecular characterization of Moroccan watermelon mosaic virus and a potyvirus isolate from Eastern Sudan. Plant Dis 85:547-552.

Lira R (1991). Estudios taxonomico y ecogeografico de las cucurbitaceae de Latinoamerica. $1^{\text {st }}, 2^{\text {nd }}$ and $3^{\text {rd }}$ Biannual report (Jan.-Aug. 1991) Rome, IBPGR.

Palukaitis P, Roossinck MJ, Dietzgen RG, Francki RIB (1992). Cucumber mosaic virus. Adv Virus Res 41:281-348.

Palukaitis P, García-Arenal F (2003). Cucumoviruses. Adv. Virus Res. 62:241-323.

Paris HS (1989). Historical records, origins and development of the edible cultivar group of Cucurbita pepo (Cucurbitaceae). Econ. Bot. 43: 423-443.

Provvidenti R (1996). Diseases caused by viruses. In: Zitter TA, Hopkins DL, Thomas CF (eds.). Compendium of Cucurbit Diseases. St. Paul MN, USA, APS press; p:37-45.

Renner SS, Schaefer H, Kocyan A (2007). Phylogenetics of Cucumis (Cucurbitaceae): Cucumber (C. sativus) belongs in an Asian/Australian clade far from melon (C. melo). BMC Evolutionary Biology 7:58.

Tomlinson JA (1987). Epidemiology and control of Virus diseases of vegetables. Annals of Applied Biology 110: 661-681.

Yuki VA, Rezende JAM, Kitajima EW, Barroso PAV, Kuniyuki H, Groppo GA (2000). Occurrence, Distribution, and Relative Incidence of Five Viruses Infecting Cucurbits in the State of Sao Paulo, Brazil. Plant Dis 84:516-520. 